\title{
THE PUBLIC ACTION LANGUAGES APPROACH TO PUBLIC AFFAIRS
}

\author{
ASSUNTOS PÚBLICOS E A ABORDAGEM DAS LINGUAGENS DE AÇÃO PUBLICA \\ ASUNTOS PÚBLICOS E EL ENFOQUE DE LOSLENGUAJES DE ACCION PÚBLICA
}

\begin{abstract}
The paper starts from the observation that the State is not synonymous with public affairs. Given a more polycentric approach in which the public, or publics, are key and independent social actors, amongst others, it questions the assumed central role of public policy in articulating the discussion and provision of public goods and services. The paper takes a historical perspective on the emergence of the notion of policy at different moments in the English language and examines three periods when English-speaking democracies significantly broadened the public affairs agenda: Roosevelt's New Deal in 1933, the 1945 British Labour Government, and the Johnson administration (1963-1968). All three cases featured practical breakthroughs, with new approaches to some difficult issues but with little, if any, discussion of policy. The paper questions the centrality and inevitability of public policy and concludes by arguing for a public action languages approach to the study of public affairs.
\end{abstract}

KEYWORDS: Social languages, public affairs, critical policy studies, Johnson administration, public action.

Peter Spink - peter.spink@fgv.br

Professor at Fundação Getulio Vargas, Escola de Administração de Empresas de São Paulo - São Paulo - SP, Brazil

Artigo convidado

\section{AUTHOR'S NOTE}

An outline version of this paper was presented at the 11th International Conference on Interpretive Policy Analysis, University of Hull, UK, in 2016, following a previous paper with Gabriela Toledo Silva given at the International Political Science Association meeting in Montreal 2014 where we received valuable comments from Hal Colebatch and Robert Hoppe. I am very grateful for the help provided by the Lyndon B. Johnson Presidential Library's archival staff and especially Archivists Brian C. McNerney and Allen Fisher in teaching me about the day-to-day of the Johnson period and in discussing some of the ideas in this paper, and also for the important contributions from fellow researcher Robert Wilson at the LBJ School of Public Affairs, author of a key publication on the Johnson period, as well as Lupicínio IñiguezRueda, Mario Aquino Alves, and Mary Jane Paris Spink who helped with many of the earlier formulations.

This project was supported by a grant from the Brazilian Conselho Nacional de Desenvolvimento Científico e Tecnológico - CNPq (306927/2011-0)

DOI: http://dx.doi.org/10.12660/cgpc.v21n70.64366 
Peter Spink

Resumo

Este artigo parte da observação feita por autores envolvidos com diferentes aspectos das acões públicas, uma vez que o Estado não e sinônimo de assuntos públicos. Do ponto de vista policêntrico, no qual o público ou públicos são atores-chave e independentes, questiona-se o papel central que a política pública supostamente assumiu na articulação da discușsão e provisão de bens e serviços públicos. O artigo adota uma perspectiva histórica da emergência da politica pública na língua inglesa em diferentes momentos e focaliza três períodos reconhecidos como aqueles nos quais as democracias anglófonas deram passos significativos para a ampliação da agenda de debate dos assuntos públicos: o New Deal de Roosevelt, 1933; o Governo do Partido Trabalhista britânico, 1945, e as administrações Johnson (1963-1968). Em todos esses casos, houve inovações muito práticas no tratamento de questões muito difíceis, mas com muito pouca - se houve - discussãa de política pública. Considerando que fala e ação andam juntas, quais outras linguagens sociais (para usar o termo de Bakhtin, 1986) estavam disponíveis? Ao apontar que elas eram muitas, das quais a maior parte continua presente e bastante ativa hoje, o artigo questiona a centralidade e inevitabilidade da política pública e propõe abordar linguagens de ação pública para o estudo dos assuntos públicos.

Palavras-chave: Linguagens sociais, assuntos públicos, estudos críticos de política pública, Administração de Johnson, ação pública.

\section{Resumen}

El artículo parte de la observación, hecha por autores que participan en diferentes aspectos de la acción pública, de que Estado no es șinónimo de asuntos puúblicos. Teniendo en cuenta un enfoque más policéntrico en el que público o públicos, ellos mismos son claves y los principales agentes sociales, cuestiona entre otras cosas la asunción del papel central que la política pública se supone que tiene en la articulación de la discusión y la provisión de bienes y servicios públicos. El artículo asume una perspectiva histórica sobre la aparición de las políticas en diferentes momentos en el idioma inglés y mira con más detalle tres períodos que son ampliamente reconocidos como momentos donde las democracias de habla inglesa hicieron avances significativos hacia la ampliación de la agenda de los asuntos públicos: el 'New Deal' de Roosevelt en 1933; el Gobierno de los laboristas británicos de 1945; y las administraciones de Johnson (1963-1968). En todos estos casos, hubo avances muy prácticos, con nuevos enfoques sobre algunas cuestiones muy difíciles, pero en todo caso con muy poca discusión de las políticas. Teniendo en cuenta que la acción y el habla van de la mano, ¿qué otros lenguajes sociales (para usar el término de Bakhtin, 1986) estaban disponibles? Al șeñalar que estos eran muchos y que continúan siendo muchos y muy activos en el presente, el artículo cuestiona la centralidad y la inevitabilidad de la política pública y concluye defendiendo una aproximación de los lenguajes de la acción pública para el estudio de los asuntos públicos.

Palabras clave: Lenguajes sociales, asuntos públicos, estudios críticos de política, administración de Johnson, acción püblica.

\section{INTRODUCTION}

The starting point for the paper is the observation that the State in its different versions is not synonymous with public affairs, and "the reach of public action goes well beyond the doings of the state, and involves what is done by the public" (Dreze \& Sen, 1989). More recently, this theme has been developed in different ways, especially in the French social sciences, but the broad proposition remains that it is necessary to move away from a singular state-centered model to a polycentric approach to action, institutionalities, and social organizations that recognizes divergence and antagonism
(Commaille, 2014). The public has never relinquished control over what it regards as public. Indeed, in many parts of the third world, this engagement has gone far beyond debates and pressure on public issues, for it has usually been up to the public, or publics, to provide for themselves - building houses, organizing day care centers, creating free health services, and sustaining communities. As a result, state-public relations are far from simple. Why, therefore, should we assume that they can be neatly wrapped up within a single way of enacting (performing and talking) public concerns, as, for example in the current ubiquitous presence of public policy? 
Against this background, my paper makes four points. The first is that the centrality that "public policy" has come to occupy in publications, courses, conversations, and curricula in the various disciplines that make up the public field has gone way beyond its analytical usefulness. It has become a critical synonym for any type of governmental action, an observation already made by anthropologists, interpretive policy analysis, and the "policy work" school (Shore \& Wright, 1997; Fischer, 2003; Colebatch, 2006; 2006b; Colebatch, Hoppe \& Noordegraaf, 2010). Here there is much that can still be discussed, but I prefer to go in a different direction and suggest that a) this centrality is recent and $b$ ) will be temporary.

The second point is that "public policy" is not the only action language present in the public arena. There are many others, and each in its different way makes public things happen. Many have also had their central moments but have remained in the spaces and places that they created, with the professionals that they reproduce and with their heterogeneous networks of materialities, socialities, and, we might add, institutionalities (Law \& Moll, 1995; Latour, 2005).

The third point is that if "public policy" is only one amongst many different social languages for being and doing public affairs enacting public responses to social affairs - we need to develop some kind of minimal starting point that allows us to discuss this complex plurality of possibilities. Here we suggest adopting "public action languages," which is understood critically to include not just the actions of government for the public but the action of the public when putting independent pressure on government or in creating alternative collective responses to public needs (the actions of the public for the public).

The fourth point is to recognize that we as scholars and researchers are very actively and performatively (Austin, 1962; Bakhtin, 1986; Hacking, 1999; Searle, 1995) present in these different social languages and in doing so contribute, following Foucault, to their disciplinarity (Burchell, Gordon \& Miller, 1991). This may seem an easy conclusion for a conference, but for those who work more directly in public affairs and with their multiple interfaces, it carries important consequences.

\section{AN INITIAL EXAMPLE}

Article 288 of the Treaty of Lisbon on the functioning of the European Union (EU) establishes five ways in which the EU can exercise its competence: regulations, directives, decisions, recommendations, and opinions. Directives are "binding, as to the result to be achieved, upon each Member State to which [they are] addressed, but shall leave to the national authorities the choice of form and methods."

In the aftermath of the Second World War, we will find the same term - part of basic military language - playing a key role in articulating and rebuilding civil administrations in the allied occupied territories. Military leaders faced not only the questions of demobilization and security but also those of different peoples in shock, without food, work, and often without shelter. A recent study by the historian Chris Knowles (Knowles 2014) has traced part of the story of reconstruction. In the words of General Bernard Montgomery's 
Deputy, General Brian Robertson, written in January 1946,

The directives were not many and much was left to the initiative of individuals.... the (military) detachments entered into a land of desolation and bewilderment. Government above the level of the parish council had ceased. Everything was in disorder; people were stunned and helpless..."First things first" was the motto when the Military Government first raised its sign in Germany (cited in Knowles, 2014)

The directives focused on rebuilding economic and political life. In Knowles's description,

Unlike earlier wartime directives, the new directive identified steps to be taken to reconstruct German economic and political life, address shortages of food, fuel and housing, improve transport facilities, reopen schools, permit freedom of assembly, licence political parties and prepare for future elections. (Knowles, 2014)

Directives are a form of social action language that identifies goals and responsibilities but, like in the Treaty of Lisbon, does not go into the methods. Unlike policy, there is no discussion of implementation, which is left up to those involved who are assumed to be able to find a way through. Whilst the term may fit within the conversations of military strategists, there is no reason to restrict its use to that quarter; we can find it in use in different parts of our modern welfare states, as well as the EU. Note that Article 288 does not use the word "policy," although the word crops up continually in discussions of different issue areas, such as the Common Agri- cultural Policy (CAP):

The common agricultural policy (CAP) is aimed at helping European farmers meet the need to feed more than 500 million Europeans. Its main objectives are to provide a stable, sustainably produced supply of safe food at affordable prices for consumers, while also ensuring a decent standard of living for 22 million farmers and agricultural workers. (EU, Agriculture and Rural Development, overview, June 2016)

The CAP has hundreds of different actions in different areas, and half-an-hour wandering around the CAP section of the EU site will be enough to identify many different ways of talking about action. What the public action languages approach proposes is not that one expression is correct or that there is a specific definition to each term that enables it to be placed in order on a conceptual bookshelf. Rather, it is to take all of them seriously and look at the realities they enact. At times, they cross each other and collaborate; at times, each goes its own way; and at times, they can collide. In all cases, they have consequences for the political economy of public action. Policy is not the solution - it is just one place to start.

\section{Policy 1 and Policy 2}

Some kind of idea about policy as an orientation of action existed when dictionaries began to be compiled in the late medieval period, but it was very much an everyday usage, as in the expression "honesty is the best policy" or a bit later in relation to Ireland, "such was the crafty policy of the clergy." It takes a while before the term appears in government or public affairs, but when it does, it is always 
within this notion of a posture or a position on a particular question and nearly always in relation to foreign affairs. Here is one of the great figures of the 18th Century UK Parliament, William Pitt the Elder, addressing the House of Lords:

My Lords, I cannot agree with the noble duke, that nothing less than an immediate attack upon the honour or interest of this nation can authorize us to interpose in defence of weaker states, and in stopping the enterprises of an ambitious neighbour. Whenever that narrow, selfish policy has prevailed in our councils, we have constantly experienced the fatal effects of it. (Jones, 1914)

Gabriela Toledo Silva and I have traced the term across many different places and spaces (Spink \& Toledo Silva, 2014), but suffice it to say that this idea of a posture or orientation will be basically all there is until well into the twentieth century. We like to call this Policy 1 , and, indeed, even the Common Agricultural Policy of the EU is more like Policy 1 than the more complex notions of policy that we can find today. It is a position or a posture: help farmers feed the European population and also maintain a fair standard of living. The same idea of a posture is present in the very few mentions of the term in Lasswell's 1936 text (only seven times in the text and three in the appendix). So those who use the phrase "who gets what, where and how" as the definition of policy have not read the book.

This is quite different from the public policy we start to find, especially in the early 1970 s, when the policy sciences begin to assume center stage in the USA, or in the UK, where the idea of Senior Policy Advisors and Policy Planning Units was part of the 1968 Fulton Report, and the Central Policy Review Staff was introduced into Prime Minister Edward Heath's Cabinet in 1971. This is the public policy of our textbooks, our different theories of the policy process, our classes, studies of implementation, and our schools: what we might call Policy 2.

There is no starting point for this shift; it is gradual drift, and whilst it is present in some of the pages of Lerner and Laswell's 1951 text, Policy Sciences, it will have to pass through discussions of complexity, planning, and systems before consolidating itself as a term in the USA and UK in the 1970s, and even later elsewhere. Lasswell argued in his introduction that policy sciences was a new term that should not be used as a synonym for any other expression in use. He gave two reasons for its importance, the first being to recognize the technical contributions of academic disciplines to the resolution of public issues, which, Incidentally, is hardly innovative, as any history of the Royal Society and its counterparts will show.

The second reason is the importance of studying the policy process itself. This is the key dimension; it builds on the discussion about interdisciplinary fields in operations research but, in doing so, declares that something exists: the policy process. Posture or position (Policy 1 ) is not a process; it results in statements such as "if you invade Portugal, you will have to deal with the British Navy." However, when we declare that something is a process, we are suggesting something else: that forming and implementing policy - and, later, public policy - is something very real and important and should be stud- 
ied and improved. Here it is easy to fall into Ryle's category mistake (1949) and assume that what we are studying is an empirically valid concrete and natural object. This was certainly the case during what Goodin, Rein, and Moran called the "high modern period of public policy" (2006), and its effects continue to be widespread today in what Colebatch, Hoppe, and Nordegraaf have critically called the narrative of "authoritative instrumentalism":

In the narrative of authoritative instrumentalism, governing happens when 'the government' recognizes problems and decides to do something about them; what it decides to do is called 'policy'. The narrative constitutes an actor called 'the government' and attributes to it instrumental rationality; it acts as it does in order to achieve preferred outcomes. This is not necessarily the way that practitioners experience the policy world, however. (p. 15, 2010)

Our argument follows the important lead given by Colebatch's "policy work" approach (Colebatch, 2006b; 2010) and the performative approach to policy studies of Hoppe and Colebatch (2016) but, in doing so, takes a step further and proposes that "policy" is only one of the languages in use for doing public affairs.

The policy turn and other action languages in Brazil

Many ideas are introduced into the social sciences; sometimes they take off quickly, and in other cases, they move slowly. It is this second feature of the "policy turn" that sparked our original questioning. In Brazil, which is not out of touch with the scientific mainstream, public policy only took root at the end of the 1990s and then rapidly expanded in the following decade when the number of master's and doctoral dissertations using "policy" as a key concept jumped over 1,000\%. A 2011 literature review commented that $65 \%$ of all Brazilian academic journal articles dealing with the topic of public policy were published between 2006 and 2010 . We now have specialist policy advisors in various levels of government, policy schools, and obligatory courses on public policy as a required part of undergraduate public administration training. A review of the digital archives of three leading Brazilian newspapers shows the same trend: virtually nothing (13 mentions) in the 1960s and all Policy 1, 79 in the 1970s (mixed 1 and 2), 392 in the 1980s, 2,068 in the 1990s, and 11,086 in the 2000s. Policy moved into France only in the 1980s and a bit later into Spain, where one of the leading political scientists commented that it seemed gibberish at first compared to the usual discussions of laws, norms, and regulations.

Brazil went through a transition from military to democratic rule in the 1980s and, by the 1990s, was being seen as an example of local government innovation (for example the school grant program and participative budgeting, Spink \& Farah, 2008). Given that these did not drop out of the sky and given that no public policy process was in sight, how did those involved talk to each other about what they were doing and enacting in public affairs? These conversations must have been fairly effective, for they generated actions that drew a lot of international attention. (Similar processes can be found in other Latin American countries). Fitting them 
into a box as "policy experiments" as Rondinelli (1993) suggested will not work because those who produced them did not use the word. Indeed, they were more than likely to talk about projects, activities, and rights, which is a very different and much more immediate mobilizing framework (Spink, 2013). How were they talked into being, and what has happened to these different social languages with the later widespread adoption of public policy? We can say in hindsight that they were policies, but that is to fall into the trap of historical "presentism," interpreting the past through the present. How did they manage to get by without public policy as an organizing frame? Indeed, we might ask, was it public policy as an organizing expression that provided the major advances of socio-economic democratic development and our modern welfare states? If not, what is its contribution?

The social languages of key democratic developments

Recognizing the clear USA and UK ascendance over the early days of the public policy field (indeed, it begins with the words themselves), it seems to make sense to pay more attention to what took place in the public administration history of their governments, especially when there were major breakthroughs in service provision, and to look at the role that policy played.

In the middle of the Great Depression, Franklin Roosevelt won a landslide victory in the November 1932 presidential election. Supported by a very able group of academics, lawmakers, and social liberals, both men and women, he produced a flood of bills in his first 100 days in office that changed the social landscape forever. (See for example the work of his Secretary of Labor, Frances Perkins, in Downey, 2009). National planning in the pre-Roosevelt period was a term associated with Soviet Russian centralism, yet Roosevelt was able to introduce a totally new concept of public sector organization and show that regional planning could be democratic (the Tennessee Valley Authority (TVA)). The TVA reorganized floodwaters, built hydroelectric schemes and locks, and led programs and projects in regional development over an area that included major bits of a number of states and, in doing so, consolidated regional planning as part of democratic society. Yet there was no department of planning in the TVA and certainly no "plan" and also no policy. In its practice, TVA was much less a planning agency and more an action theory about planning the interests of government, the private sector, and the community in a collective and cooperative way. It ran into many difficulties, for the original presidential message charged it not only with the "broadest duty of planning for the proper use, conservation and development of the natural resources of the Tennessee River drainage basin.... [f]or the general social and economic welfare of the Nation" but also gave it the "necessary power to carry these plans into effect." There was to be much public and academic discussion as a result (Selznick, 1949) but the TVA was effective in the long run.

David Lillienthal, the TVA's second Chairman, summed up this experience in a much reprinted paperback entitled "TVA: Democracy on the March" (1944), which he saw as the TVA's report to its stockholders, that is, the American public. For current students of planning theory, some of the discussion on 
planning will seem very much up to date, as the following extracts show:

The reason that the TVA Plan is not available is that there is no such document. Nor is there one separate department set off by itself, where planners exercise their brains...[...] The TVA is a planning agency, the first of its kind in the United States. The great change going on in this valley is an authentic example of modern democratic planning; this was the expressed intent of Congress, by whose authority we act. But through the years we have deliberately been sparing in the use of the terminology of "plans" and "planning" within the TVA and outside, and those terms have hardly appeared thus far in the book. For the term "planning" has come to be used in so many different senses that the nomenclature has almost lost usefulness, has even come to be a source of some confusion... (p. 207)

The TVA idea of planning sees action and planning not as things separate and apart, but as one single and continuous process.... [...] The idea that planning and responsibility for action may and should be divorced - the maker of plans having little or nothing to do with their execution - follows the analogy of the planning of a house, an office, any fixed structure. But the analogy is a mistaken one. For the development of a region is a course of action; it has no arbitrary point of beginning and goes on and on with no point of completion. The individual acts that make up regional development are the day-to-day activities of plowing a particular field, harvesting timber from a particular tract, the building of a factory, a church, a house, a highway. TVA's purpose was not the making of plans

$$
\text { but that a valley be developed..... (p. 214) }
$$

As these excerpts show, Lillienthal was not intuitively wandering around the Tennessee Valley without a social action language in which to find himself, his colleagues, technical advisors, local farmers, business people, and politicians. His text is a social product, a way of talking, making sense, and enacting that linked many different social actors but also generated questions for others. Much of what we today take as obvious in relation to rural development, water drainage, test farming, and agricultural extension was heavily influenced by the TVA, and the Tennessee River is no longer the ferocious monster of floods and landslides of the early 1930s.

The result of the 1945 elections in the United Kingdom had a number of similarities to the Roosevelt period. The elections resulted in a landslide for the Labour Party, and in the following five years, no less than 347 acts of parliament were introduced, radically changing the organizational and institutional landscape of the British public sphere. These included implementing the 1942 Beveridge Report on Social Insurance and Allied Services, creating the National Health Service (NHS), raising the school leaving age to 15 , nationalizing key critical areas for industrial infrastructure, and building over a million homes, amongst many other more local actions. More important still, even with a reduced Labour majority in 1950 and a Conservative victory in 1951, the resulting bipartisan post-war consensus in favor of the Welfare State was to remain firm until 1970.

It is more than common to find references to the Beveridge Report in relation to Social Policy, similarly to how the Lasswell text of 
1936 is given as the definition of public policy. Beveridge does use the term in the title of part 6 of the report, Social Security and Social Policy, but there is no use of the term in the text of the chapter itself. The few uses (10) are very much within the Policy 1 frame. Here are two examples:

8. The second principle is that organization of social insurance should be treated as one part only of a comprehensive policy of social progress. Social insurance fully developed may provide income security; it is an attack on Want. But Want is only one of five giants on the road of reconstruction and in some ways the easiest to attack. The others are Disease, Ignorance, Squalor and Idleness. (p. 6)

.... The State with its power of compelling successive generations of citizens to become insured and its power of taxation is not under the necessity of accumulating reserves for actuarial risks and has not, in fact, adopted this method in the past. The second of these two distinctions is one of financial practice only; the first raises important questions of policy and equity. Though the State, in conducting compulsory insurance, is not under the necessity of varying the premium according to the risk, it may decide as a matter of policy to do so. (Paragraph 24, p.13)

Despite the many years separating the two, it is very probable that Beveridge would have understood Pitt the Elder, and Pitt although finding it somewhat strange that governments were concerned with such matters - would have had some sense of what Beveridge meant as a "matter of policy." Both are linked by Policy 1, policy as a position or stance. However, the way that they worked the affairs of the day would no doubt be different. How did Frances Perkins and Roosevelt discuss the labor affairs of the day during the 1930s, or Aneurin Bevan, the mining trade unionist, discuss with colleagues, including his wife - a fellow Member of Parliament and miner's daughter - the crafting of the NHS, one of the great social breakthroughs of the twentieth century? What were the action languages in use? The NHS was and continues to be the National Health Service - "service" not "system," as it is mistakenly referred to in various parts of the world. How was it talked into action? What did they understand by a "service"?

\section{POLICY, DOMESTIC POLICY, AND PUB- LIC POLICY: THE JOHNSON ADMINIS- TRATION AS A TRANSITION SITE}

The final example comes from the Johnson administration (1963-1968) and the Great Society programs in health care, education, civil rights, poverty reduction, and rural and urban development amongst others. Surely, that was the moment when public policy - so we are told in many textbook introductions swept into the government arena along with implementation, evaluation, and think tanks. The answer, again, is negative as my current research in the archives of the Johnson Presidential Library at the University of Texas at Austin shows. My focus is on the dayto-day documents and letters of the Johnson administration, his key advisors and staff, his letters, and conversations, as well as the construction of some of his major addresses.

The Johnson period in the domestic arena is very much like the UK post-war period, but with a much stronger drive for equity 
Peter Spink

and equal opportunity both for the poor and for the black population (for a recent appraisal of the period, see Wilson, Glickman \& Lynn, 2015). There were many bills and programs bringing new ideas to the fore, but even though people may today talk about Johnson's social policy, that is in hindsight, for Johnson himself and his team did not. There were many conferences with debates on what needed to be done, some signs of the shift, such as an early scheme for White House interns, and his staff may talk about domestic policy in contrast to foreign policy, but that is about it. The archivists of the library confirmed this impression. The language was that of bills, rulings, programs, and budgets. The Office of Equal Opportunity (OEO), a driving force for change under Sargent Shriver (who had been the first Director of the Peace Corps under President Kennedy) and joint creator along with the Departments of Health and Human Services of the "headstart" program to provide early education and nutritional support for low-income children and their families, had an Office of Research, Plans, Programs, and Evaluation. The language of the Planning Programming Budgeting System (PPBS) was brought into the mainstream of public administration in 1965, following Robert McNamara's earlier work in the Department of Defense. Johnson himself was very concerned about the effectiveness of government, sending a special message to Congress in March 1967 on the quality of American government and was highly critical of excessively bureaucratic communication, the use of which he had referred to in a 1964 cabinet meeting as "gobbledygook." Evaluation was also present as this citation from W. Gorham, then Assistant Secretary for Planning and Evaluation at the Department of Health Education and
Welfare (HEW), demonstrates:

\begin{abstract}
The very process of analysis is valuable in itself, for it forces people to think about the objectives of Government programs and how they can be measured. It forces people to think about choices in an explicit way. (Cited in Lynn, 2015, p. 382)
\end{abstract}

There is no doubt about the concern for effective government; it was just that these concerns and an amazing array of actions did not need policy to serve as a hierarchical and authoritative focus. The use of policy could be found in the offices of Washington, however it was very much as Policy 1 , an expression of orientation and position. It can be found in the State Department where from 1947 the Policy Planning Staff served as a source of independent analysis and advice for the Secretary of State. Johnson too would have no problem using the expression within the arena of foreign affairs, as in the introduction to an important address on Vietnam in April 1965 at Johns Hopkins University entitled "Peace without Conquest":

\section{My Fellow Americans}

Last week seventeen nations sent their views to some dozen countries having an interest in South East Asia. We are joining these seventeen countries and stating our American Policy which we believe will contribute towards peace in this area.

The word "policy" can also be found, very occasionally, being used by members of Johnson's own White House staff in a similar way to refer to the domestic arena (domestic policy) or to matters of personnel administration (the administration's policy on executive privi- 
lege) but never more than that.

On May 22, 1964, six months after Kennedy's death on November 22, 1963, Johnson made a keynote address to graduating students at the University of Michigan, which is remembered as the "Great Society address." (Many of his staff worked on the address, as did some highly skilled writers, and it is seen as the moment when Johnson sets the basis for his coming electoral platform. What is interesting about the address is not so much the final text, which does not mention the word "policy" at all, but the various suggestions along the way, made by aides and staff in internal memoranda and hand-written notes on different versions. Here again, it is clear that policy, if anything, was something very broad and in the background. Here are two suggestions, one in the early days of the speech and the second in relation to the third draft (LBJ - Statements 1964).

We do not serve ourselves or our society by speaking or heeding past answers - simple solutions - or petty platitudes. For this complex age, there are no uncomplicated answers - in politics, in foreign policy, in business decisions, in labor negotiations, and least of all in raising our children.

From the earliest days of the Republic we have struggled to protect the life of our nation and preserve the liberty of our citizens that we may pursue the happiness of our people. Our success in that pursuit is the test of our success as a nation. It underlies all our policies, our programs and our prospects for the future.

Here, for the reader's interest, is part of the address as it was given, showing very clearly that there is a coherent action language present, that things will take place, as indeed they did, but that the language of action is not that of public policy:

[...] So I want to talk to you today about three places where we begin to build the Great Society: in our cities, in our countryside, and in our classrooms. Many of you will live to see the day, perhaps 50 years from now, when there will be 400 million Americans, four-fifths of them in urban areas. In the remainder of this century urban population will double, city land will double, and we will have to build homes, and highways, and facilities equal to all those built since this country was first settled. So in the next 40 years we must rebuild the entire urban United States. [...] A second place where we begin to build the Great Society is in our countryside. We have always prided ourselves on being not only America the strong and America the free, but America the beautiful. Today that beauty is in danger. The water we drink, the food we eat, the very air that we breathe, are threatened with pollution. Our parks are overcrowded, our seashores overburdened. Green fields and dense forests are disappearing. [...] A third place to build the Great Society is in the classrooms of America. There your children's lives will be shaped. Our society will not be great until every young mind is set free to scan the farthest reaches of thought and imagination. We are still far from that goal [...]

These are three of the central issues of the Great Society. While our Government has many programs directed at those issues, I do not pretend that we have the full answer 
to those problems. But I do promise this: we are going to assemble the best thought and the broadest knowledge from all over the world to find those answers for America. I intend to establish working groups to prepare a series of White House conferences and meetings on the cities, on natural beauty, on the quality of education, and on other emerging challenges. And from these meetings and from this inspiration and from these studies, we will begin to set our course towards the Great Society. The solution to these problems does not rest on a massive program in Washington, nor can it rely solely on the strained resources of local authority. They require us to create new concepts of cooperation, a creative federalism, between the national capital and the leaders of local communities.[...]

An inside look at the daily working of the White House and memos from staff, or at those key agencies that spearheaded the "Great Society" push, leaves no doubt that a lot of action is going on, but it is referred to through programs, proposals, and projects, as in Shriver's testimony on the Office of Equal Opportunity (OEO) before the US Senate on August 19, 1966, or when leading academic deans wrote in support of the OEO in response to suggestions that it should be dismantled (LBJ - FG - 1966).

Public policy as a field of study and a language to organize public affairs was certainly strengthened by the fact that many of the actions initiated in the Johnson period went on to be later discussed in policy terms, or that the concern with evaluation would lead to later discussions on implementation, but to suggest that one caused the other would be incorrect. "Policy" as an action language did not orchestrate what was a tremendous and often undervalued push over a wide social arena. In major events such as the White House Conferences, it is possible to see that the idea of policy is beginning to pop up in comments by university-based academics, for example in the Conference on Education (July 20-21 1965), which stated, "critical problems in urban education may more often be at a policy rather than a program level," or comments about the importance of "policy planning" in federal-state partnerships. However, when the US Congress passed the Elementary and Secondary Education Act on April 9, 1965, it used the language not of government policy, or of public policy, but of a policy of the United States, an expression already present in foreign affairs:

In recognition of the special educational needs of low-income families and the impact that concentrations of low-income families have on the ability of local educational agencies to support adequate educational programs, the Congress hereby declares it to be the policy of the United States to provide financial assistance... to local educational agencies serving areas with concentrations of children from low-income families to expand and improve their educational programs by various means (including preschool programs) which contribute to meeting the special educational needs of educationally deprived children (Section 201, Elementary and Secondary School Act, 1965).

By the end of the Johnson period when some of the major achievements were being written about, those directly responsible would continue to talk about programs and projects, but external commentators would already be in- 
troducing the language of policy as a device very much in the foreground. In one of the various books on social affairs that were in circulation at that time, a preface by Swedish development economist Gunnar Myrdal makes use of policy in a way that would be recognized today:

A dramatic change in American attitudes towards the social problem is under way. The nation is finally - and rather suddenly - becoming prepared to accept the welfare state. [...] Broad policy measures which a few years ago would have seemed to be radical and unacceptable are now becoming part of practical policy. The swelling flood of statistical investigations devoted to the poverty problem, conferences, seminars, books and articles, speeches and policy declarations, give expression to this catharsis at the same time as they spur it on. (p. i)

We are increasingly coming to recognize as part of this great catharsis that not only social security policies but almost all other policies - agricultural policies, taxation policies, housing policies, minimum wage legislation, and so forth - have followed the perverse tendency to aid the not-so-poor, while leaving a bottom layer of very poor unaided. The War on Poverty will therefore have to be fought on many fronts and will in the end have to imply not only an enlargement but a redirection of all economic and social policies. (p. viii)

Soon, Policy 2 would be taking center stage with such events as the first issue of the journal Policy Sciences in 1970 and Pressman and Wildavski's introduction of the problems of implementation in 1973. It is difficult to guess what Johnson would have thought of the policy implementation relationship for he was known as a somewhat overpowering figure, and at six foot three-and-a-half, he had a lot of presence. Certainly, he was much more at home with programs, bills, projects, budgets, and results.

The point that the public action languages approach seeks to make is that these and many other social languages that have contributed over time to the multiple enactments of public affairs have not gone away. The normative idea that they have been domesticated within the articulating framework of public policy, each occupying its rightful place in a dictionary of action, does not stand any serious empirical test. Plans, projects, systems, issues, rights, budgets, directives, decisions (and decisions and decisions), as well as laws, bills, and the multiple languages of the social movements, including the burning tires, massed protests, and other ways of talking publicly, continue, as does Policy 1 as an orientation, a position, or a stance - an answer to the question "where do you stand?"

\section{THE PUBLIC ACTION LANGUAGES AP- PROACH}

What the public action languages approach argues is that centrality is a temporary state of ascendance and, at the practical level of public affairs, is usually ignored. Planners may have seemed powerful in urban affairs when talking about instruments, but the budget office keeps doing the budget, and protest groups will take to the streets. Policy analysts may seem to be an essential part of the current government, but project managers are taking care of projects; front-line 
workers are negotiating decisions; and faithbased organizations are moving into vulnerable areas and trying to be useful. Some may feel comfortable with the distinction between policy formation and implementation whilst others will be concerned with getting things done. Mayors may have strategy teams, but when students organize a school sit-in, or the homeless march into vacant lots and set up tented villages, they are the first to take decisions and try to respond to their demands. As can be expected, new terms for enacting public affairs are beginning to appear and vie for ascendance: for example, deliberative democracy and governance. Key here is our argument that any and all of these are much more than perspectives on public affairs; on the contrary, they enact different ontologies of public affairs - they are, for all practical purposes, different public affairs.

Public policy as the self-conscious, technical, and politically exempt policy envisaged by Lasswell and the policy sciences scholars may be outgrowing its usefulness, despite the size of our conferences and the amount of literature being produced. Certainly, we need to think more about the circumstances of its appearance at particular times in different countries. Could it that we need to see Policy 2 as a consequence of social democracy, part of its institutional governmentality, rather than as a producer of major change? In that sense, we should discuss its contribution and be critical in the same way as we might critically analyze budgeting, accountability, planning, projects, direct democracy, and the language of issues, as well as many other ways of talking publicly - including Policy 1 .

However, much more important is the recog- nition that public affairs go beyond the sphere of actions and intentions of government. Many other voices are involved in the dispute over what is "public," and in many other social languages. Some of these languages may converge others may move entirely in their own tracks; and yet others collide. Over the years, many have lost their lives or suffered in other ways the consequences of arguing that something was public. Others, more present in the Third World and in the absence of an effective state, have gone ahead to create their own public arena of local services. Rethinking public affairs from the broader approach of public action and accepting its multiple and disjointed languages and its hybrid characteristics (Spink, Hossain \& Best, 2009) could be key to understanding emerging patterns of "public" and developing alternative approaches to democratic action. We need, remembering Garfinkel (1967), to take more seriously how people find and lose each other amongst the spoken practices of everyday public action.

\section{REFERENCES}

Austin, J. L. (1962) How to do Things with Words. Cambridge MA: Harvard University Press.

Bakhtin, M. M. (1986) Speech Genres and other Late Essays. Austin TX: University of Texas Press.

Burchell, G., Gordon, C., \& Miller, P. (1991) The Foucault Effect: Studies in Governmentality. Chicago: University of Chicago Press.

Colebatch, H. K. (2006) (ed.) The Work of Policy: An International Survey. Lanham MD: Lexington Books. 
Colebatch, H. K. (2006b) What Work Makes Policy. Policy Science 39(4), 309-321.

Colebatch, H. K. (2010) Giving Accounts of Policy Work. In: Colebatch H., Hoppe R. \& Noordegraaf, M. (eds.) Working for Policy. Amsterdam: Amsterdam University Press (pp. 31-43).

Colebatch H., Hoppe R., \& Noordegraaf, M. (eds.) (2010) Working for Policy. Amsterdam: Amsterdam University Press.

Commaille, J. (2014) Sociologie de L'Action Publique. In: Boussaguet L., Jacquot S. \& Ravinet P. (eds.) Dictionnaires de Politiques Publiques 4th edition. Paris: Sciences Po. Les Presses. pp. 599-607.

Downey, K. (2009) The Woman behind the New Deal: The Life of Frances Perkins, FDR's Secretary of Labor and his Moral Conscience. New York: Doubleday.

Dreze, J., \& Sen, A. (1989) Hunger and Public Action. London: Clarendon Press.

Fischer, F. (2003) Reframing Public Policy: Discursive Politics and Deliberative Practices. Oxford: Oxford University Press.

Garfinkel, H. (1967) Studies in Ethnomethodology. New York: Prentice Hall.

Goodin, R. E., Rein, M. \& Moran, M. (2006) The Public and its Policies. In: Moran, M., Rein, M. \& Goodin, R.E. (eds.) The Oxford Handbook of Public Policy. Oxford: Oxford University Press.

Hacking, I. (1999) The Social Construction of What. Cambridge MA: Harvard University Press.

Hoppe, R., \& Colebatch H. (2016) The Role of Theories in Policy Studies and Policy Work: Selective Affinities between representation and Performation?, European Policy Analysis 2(1), 121-149.

Jones, E. (1914) Selected Speeches on British Foreign Policy. pp. 1738-1914. (available at www.gutenberg.org)

Knowles, C. (2014) Germany 1945-1949: A case study in post-conflict reconstruction. History and Policy. History and Policy Papers. org January 29, 2014.

Lasswell, H. (1936) Politics: Who gets What, When and How. New York: Whittlesey House.

Latour, B. (2005) Reassembling the Social: An Introduction to Actor-Network-Theory. Oxford: Oxford University Press.

Law, J., \& Moll, A. (1995) Notes on materiality and sociality. The Sociological Review, 43(2), 274-294

Lerner, D. \& Lasswell, H.D. (1951) The Policy Sciences: Recent Developments in Scope and Methods. Stanford, CA: Stanford University Press.

Lillienthal, D. (1944) TVA: Democracy on the March. New York: Pocket Books.

LBJ - Statements - 1964. Statements of Lyndon Baines Johnson 20th May - 23rd May 1964 Box 106, File University of Michigan Address, suggested remarks Busby, Comment on Draft between Goodwin and 
Valenti. LBJ Presidential Library, University of Texas at Austin.

LBJ - FG - 1966: Lyndon B. Johnson Presidential Library, University of Texas at Austin. File FG 11-15, 6/11/66-9/13/66 in Box 125

Lynn, L.E. Jr. (2015) Reform of the Federal Government: Lessons for Change Agents. In: Wilson, R.H., Glickman, L.E. \& Lynn, L.E. Jr. (eds.) LBJ's Neglected Legacy. How Lyndon Johnson Reshaped Domestic Policy and Government. Austin TX.: The University of Texas Press.

Myrdal, G. (1965) Preface In: Seligman B.B. (ed.) Poverty as a Public Issue. New York: The Free Press.

Pressman, J. and Wildavski, A. (1973) Implementation. Berkeley: University of California Press.

Rondinelli, D.A. (1993) Development Projects as Policy Experiments. London: Routledge.

Ryle, G. (1949) The Concept of Mind. Chicago: University of Chicago Press.

Searle, J.R. (1995) The Construction of Social Reality. New York: The Free Press.

Selznick, P. (1949) TVA and the Grass Roots: A Study in the Sociology of Formal Organization. Berkeley CA: University of California Press.
Shore, C. \& Wright, S. (1997) (eds.) Anthropology of Policy: Critical Perspectives in Governance and Power. London: Routledge.

Spink, P.K. (2013) Psicologia Social e Políticas Públicas: Linguagens de ação na era dos direitos in Eduardo Marques \& Carlos Aurélio Faria, (eds.) A política pública como campo multidisciplinar. São Paulo: Editora UNESP; Rio de Janeiro: Editora Fiocruz.

Spink, P.K. \& Farah, M.F.S.S. (2008) Subnational Government Innovation in a Comparative Perspective: Brazil. In: Sandford Borins. (ed.) Innovations in Government: Research, Recognition and Replication. Washington DC: The Brookings Institution, 2008, pp. 71-92.

Spink, P.K, Hossain, N. \& Best, N. J. (2009) Hybrid Public Action. IDS Bulletin. Retrieved from http://www.ids.ac.uk/publication/hybridpublic-action

Spink, P. \& Toledo Silva, G. (2014) Beyond Policy: Public action languages and governance from a Brazilian Perspective. 23rd World Congress of Political Science, Montreal, Canada.

Wilson, R.H., Glickman, N.J. \& Lynn, L.E. Jr. (2015) LBJ's Neglected Legacy. How Lyndon Johnson Reshaped Domestic Policy and Government. Austin TX: The University of Texas Press. 